Transformations in Tertiary Education

Theme: Engaging for Belonging

\title{
Partnerships for Learning and Belonging in Tertiary Education: A social capital analysis
}

\author{
Andrea Chester ${ }^{1}$, Alexandra Johnston ${ }^{1} \&$ Angela Clarke ${ }^{2}$ \\ ${ }^{1}$ School of Education, RMIT University, Melbourne, Australia \\ ${ }^{2}$ College of Design \& Social Context, RMIT University, Melbourne, Australia \\ Corresponding author: andrea.chester@rmit.edu.au
}

\begin{abstract}
Social capital refers to the benefits that accrue from social connections and networks. Most frequently linked with the work of Bourdieu and Putnam, the concept has found expression in the disciplines of sociology, political science and economics. In this chapter we explore the application of social capital to tertiary education practices. Specifically we examine the ways in which bonding, bridging and linking social capital can be applied to the common academic practices of student peer mentoring and staff peer observation of teaching. Findings from a range of studies show that the explicit development of trust, reciprocity, information sharing and cooperation in student and staff networks can improve learning experiences and enhance belonging. A social capital analysis of these partnerships suggests that investing in these types of partnerships amongst students and staff offers scalable, sustainable and costeffective opportunities to strengthen tertiary education.
\end{abstract}

\section{Introduction}

This chapter provides an analysis of peer partnership activities in tertiary education using the framework of social capital. The concept of social capital, with links to sociology, politics, economics and education, is used to explore the benefits that arise from peer to peer interactions, including student peer mentoring and staff observation of teaching programs. Although the concept of social capital is not widely discussed in the literature in either of these areas, the value of peer networks is at the core of both processes and social capital offers a way to think about and into these practices.

The chapter begins by describing the concept of social capital and its historical development.. We define different types of social capital. Following this introduction, we examine the literature on student peer mentoring and staff peer observation of teaching, with a focus on how these two processes can build social capital for their participants and benefit tertiary institutions. A key driver for institutional growth in the tertiary education sector is the need to foster learning and professional environments that help people work more effectively together. Using these two common practices, we show how building social capital through positive and productive peer partnership relationships develops a sense of belonging and social cohesion in a range of settings and enhances learning. Findings from a range of studies summarised in this chapter, including our own research, show that students and staff, individuals and groups, were able to effectively build both trust, engagement and social 
cohesion, key variables that are often used to measure the benefits of building social capital.

\section{Social capital}

Social capital can be understood quite simply as networks of social relations characterised by norms of trust and reciprocity. The essence of social capital is quality social relations.

Stone \& Hughes, 2000, p.20

While the term social capital is often credited to Lyda Judson Hanifan's (1916) advocacy for community engagement in rural education in the US, academic interest in the concept is relatively recent, with origins in the work of sociologist Pierre Bourdieu in the 1990s.

Bourdieu compared social capital to economic and cultural capital, describing it as a product of the number of connections a person has and the volume of the economic and cultural capital inherent in each of those members. At the same time James Coleman (1988), also a sociologist, was exploring the application of social capital in the context of education and Francis Fukuyama (1995), a political economist, was exploring its economic and political functions. But it was the American political scientist, Robert Putnam, who popularized the concept of social capital (Halpern, 2005). In Making Democracy Work: Civic Traditions in Modern Italy, published in 1993, Putnam and his co-authors argued that the relative performance of regional governments in Italy over a 20 year period was due not to innovative policy or fiscal management, but rather to levels of civic engagement and social networks, in other words, social capital. In his next work, Bowling Alone, Putnam (2000) turned his attention to North America and explored social capital in the context of civic and religious participation, workplace and social connections, altruism, volunteering and philanthropy, social movements and the internet. It was this work that captured widespread attention, within and outside academic circles.

Social capital is thus multidisciplinary in nature, drawing on sociology, political science and economics in its development and more recently finding application in disciplines from history to health science (Field, 2008). In education the roots of social capital predate Hanifan with the word found in the early writings of John Dewey. In The Elementary School Record Dewey commented on an education system that would "unlock to the child the wealth of social capital which lies beyond the possible range of his limited individual experience" (1900, p.230).

\section{What is social capital?}

With its diverse disciplinary origins it is not surprising that those writing in the area approach the concept from different perspectives. While critics have argued there is a need for clarity (Halpern, 2005; Woolcock, 2001), in essence social capital is a remarkably straightforward concept. As John Field notes, the central thesis of social capital can be "summed up in two words: relationships matter" (p.1).

In Bowling Alone, Robert Putnam (2000) described social capital as the "collective value of social networks and the inclinations that arise from these networks to do things for each other" (p.19). According to Putnam, the features of social networks - trust, reciprocity, information sharing and cooperation - are both a private benefit as well as a public good, bringing advantages to the people connected by those relationships and often for others. Like the physical capital that exists in education contexts (such as the technologies, facilities 
and resources) and human capital (such as the skill and knowledge of the staff), social capital, Putnam argued, has the potential to increase the productivity of both individuals and collectives. As Benbow and Lee (2018) explain, social capital emerges when one invests in cultivating social ties. Pamela Paxton (1999) notes that for social capital to develop those ties need to be reciprocal, trusting and involve positive emotion.

Different types of social capital have been described, with a distinction drawn between bonding social capital, exclusive relationships between like people in similar situations and bridging social capital, inclusive relationships between like people across social groupings (Field, 2008). Putnam (2000) described the former as a sociological superglue holding people together and the latter as a kind of WD40, lubricating and protecting relationships. According to Nan Lin (2001), whose work has informed social capital research in the discipline of education, the two types of social capital serve different purposes. The strong ties of bonding social capital serve to reinforce identity-focused goals. In contrast the weaker ties of bridging social capital can provide access to new resources and facilitate the achievement of instrumental goals.

While bonding and bridging social capital have been described as horizontal metaphors describing relationships between essentially homogeneous community members, Michael Woolcook (2001) identified a third and vertical form of social capital, linking social capital, which describes alliances with people who provide a "capacity to leverage resources, ideas, and information from formal institutions beyond the community" (p.14) and provide links to power outside the group.

In the following sections we use the lens of these forms of social capital to explore two common practices in tertiary education: peer mentoring for students and staff peer observation of teaching. Through the framework of bonding, bridging and linking social capital it is possible to evaluate the social capital potential of these two aspects of tertiary education practice and the ways in which these social networks are positively transforming tertiary education.

\section{Social capital in tertiary education: student peer mentoring}

Leveraging social capital amongst students offers a sustainable and efficient solution to multiple challenges currently facing tertiary education. As the number and diversity of students entering tertiary education increase (Parr, 2015), institutions need to develop efficient and effective ways to manage student transition and engagement. Peer mentoring has become a standard element in best practice models of first year transition and retention (Adams, Banks, Davis, \& Dickson, 2010). Indeed as Egege \& Kutieleh (2015) note "while not exactly a 'silver bullet', peer mentoring appears to be the single most effective way to prevent attrition and low satisfaction rates" (p.266).

Tertiary education institutions have been using mentoring for many years and several reviews of research on mentoring in education now exist, spanning more than 25 years of practice (for example, Crisp \& Cruz, 2007; Egege \& Kutieleh, 2015; Ehrich, Hansford, \& Tennent, 2004; Gershenfled, 2014; Haggard, Dougherty, Turban, \& Willbanks, 2011; Jacobi, 1991; Terrion \& Leonard, 2007). These reviews have confirmed four functions of student mentoring in tertiary education:

- emotional and psychological support

- help with academic content and subject knowledge 
- direct assistance with career and professional development

- role modeling

Together these four functions emphasise the social capital implicit in the mentoring process, underscoring the core ways in which "relationships matter" in student mentoring, from providing social support, to facilitating academic progress and professional development.

In a paper critiquing the lack of definitional and theoretical clarity in the field of mentoring, Barry Bozeman and Mary Feeney (2007, p.731) acknowledged the central role that social capital might play, defining mentoring as

a process for the informal transmission of knowledge, social capital, and psychosocial support perceived by the recipient as relevant to work, career, or professional development; mentoring entails informal communication, usually face-to-face and during a sustained period of time, between a person who is perceived to have greater relevant knowledge, wisdom, or experience (the mentor) and a person who is perceived to have less (the protégé).

In the same year Sarah Hezlett and Sharon Gibson (2007) published a comprehensive review of the alignment of social capital and workplace mentoring programs, showing how a small number of studies have drawn explicitly on social capital theory and a wider literature has implicitly aligned with social capital elements. Hezlett and Gibson provide a comprehensive argument, demonstrating how both the mentoring and social capital literatures have shared a focus on the value of relationships and common constructs including positive outcomes, negative experiences, trust and information exchange.

While social capital has been linked to mentoring in the workplace, there have been few explicit references to social capital in the tertiary education mentoring literature. Susan Gerschenfeld (2014), in a review of 20 undergraduate mentoring programs, noted that social capital had been used as a conceptual framework in only two. In the first of these, Mekolichick and Gibbs (2012) analysed benefits derived from research-focused mentoring for sociology undergraduates, noting differences in the approaches taken by first generation students and those with a family history of tertiary study, concluding that these differences could be explained by the concept of cultural capital. Gannon and Maher (2012) referenced social capital theory, drawing parallels between social capital and mentoring theory, citing three studies that have aligned both theories. It is of note that none of these studies were situated in tertiary education. Nevertheless Gannon and Maher argue that a mentoring program cognizant of social capital impact may have particular benefits for the careers of graduating students. Their program, in which final year tourism and hospitality students were mentored by alumni working in the industry, was positively evaluated by both mentees and mentors, however, the authors note their intention to more strongly underscore the social capital benefits of the program for participants in subsequent iterations.

Although social capital has rarely been explicitly addressed in the literature on tertiary education student mentoring, the dimensions of bridging, bonding and linking social capital are evident in mentoring programs.

Bridging social capital. While definitions of mentoring are diverse (Egege \& Kutieleh, 2015; Jacobi, 1991; Crisp \& Cruz, 2007), core to most definitions is a more experienced mentor partnering with a less experienced mentee. Kehoe (2007), for example, defined a mentor as "a person who is more experienced in a particular context helping a less experienced person 
achieve their goals" (p.6). Mentoring epitomizes bridging social capital, which builds relationships between like people who do not yet have well-established ties.

In most models of tertiary education mentoring mentors are typically later year students from the same discipline as the mentee. For example, in an effort to better support matureage first year paramedic students who were at risk of failing, Hryciw, Tangalakis, Supple and Best (2013) introduced a voluntary Peer Assisted Study Sessions (PASS) program, facilitated by later year mentors. Second year mentors, chosen on the basis of their academic performance, worked in pairs to facilitate groups of 25 mentees. Compared to first year students who did not attend the mentoring sessions, the 105 mentees achieved higher grades and were less likely to fail. Mentees perceived the program to improve their study and increase their confidence. They also reported these benefits generalizing to other courses. In an analysis of the mutual capital built through the exchange, benefits for mentors included perceptions of improved knowledge, communication and leadership skills as well as enhanced confidence.

In our own teaching we have used later year students as mentors. For example, in one study we described the integration of a mentoring program into a first semester compulsory psychology unit, where first year students $(N=231)$ were mentored in small groups by pairs of third year students $(N=34)$ (Burton, Chester, Xenos \& Elgar, 2013). We used a mixedmethods pretest-posttest design to evaluate the model. First year students evidenced significant improvements on the psychological literacies targeted in the program. In addition both mentees and mentors experienced an increase in deep learning and a reduction in surface learning. Mentees and mentors alike agreed that the program improved the quality of their work and facilitated a sense of belonging.

Similar pairings of first year and later year students have produced positive outcomes in a range of other disciplines, including accounting (Fox, Stevenson, Connelly, Duff \& Dunlop, 2010), biology (Goff, 2011) and education (Douglass, Smith, \& Smith, 2013). Beyond these course-focused models are examples of whole of university programs; large-scale initiatives that also use more experienced mentors from the mentee's discipline (for example, Beltman and Schaeben, 2012; Hall \& Jaugietis, 2011; Skaniakos, Penttinen, \& Lairio, 2014).

The studies described above provide examples of mentoring programs that connect first year students with more experienced students in the discipline. These programs implicitly leverage bridging social capital in order to successfully support transition, increase pass rates, enhance deep learning and academic achievement and improve retention of first year students.

In several studies benefits for mentors have also been documented, supporting the importance of reciprocity in social capital emphasised by both Putman (2000) and Paxton (1999). Beltman and Schaeben (2012) for example focused on benefits for mentors in an institution-wide program, noting four main areas of advantage: altruistic (satisfaction derived from helping others), cognitive (enhancement of skills and knowledge), social (development of networks) and personal growth (self-confidence and reflection). In our own research (Burton et al., 2013) mentors showed even more positive evaluations of the program than the first year students, strongly agreeing that the program had helped both their academic performance and sense of wellbeing. These positive outcomes were perhaps due to the layers of social capital they accrued through their work with their mentor partner as well as their work with the first year students. 
Bonding social capital. Several mentoring programs have built bonding social capital within mentee cohorts, both explicitly and implicitly, through group programs. For example, the PASS program to support mature age paramedic first year students developed by Hryciw et al. (2013), brought mentees together in groups of 25. Mentees noted the program had increased their friendship network. Similarly, the majority of first year psychology mentees in our research (Burton et al., 2013) who worked with mentors in small groups within their tutorials, reported that the mentoring program had enhanced their sense of belonging.

Linking social capital. Linking social capital connects mentees to important resources outside their discipline area. Although less frequent in tertiary education, some models of linking social capital exist in the mentoring literature. Jones and Goble (2012) for example, paired undergraduate students with an intellectual disability with mentors majoring in special education. Designed to support academic and/or social needs of the mentees, the program demonstrated positive outcomes for both mentees and mentors.

Moving beyond the use of students as mentors, research-focused staff (Mekolichick \& Gibbs, 2012) and industry practitioners (Gannon \& Maher, 2012) have also been integrated into mentoring programs, linking mentees to core knowledge and resources for professional development. With a focus on industry connection, Gannon (2012, p.442) noted

the value of developing a mentoring programme for students, who will soon enter the highly competitive, mass, graduate labour market is therefore also clearly supported by arguments and evidence from social capital theory, where social capital and ties may be the discerning factors in securing positions and advancement opportunities.

In summary, although not widely employed as a construct in the student peer mentoring literature, social capital provides a framework for explaining the impact and value of programs on both mentees and mentors. It can help describe the ways student mentoring bridges, bonds and links to transform learning experiences.

\section{Social capital in tertiary education: staff peer observation of teaching}

Social connections between teachers in primary and secondary settings have long been recognised as important ways to support the transition of new teachers as well as provide access to information, support and advice for existing staff (Baker-Dolye, 2013). These networks can increase job satisfaction and self-efficacy as well as improve practices that enhance student outcomes (Benbow \& Lee, 2018). Less is known, however, about the impact of these networks in tertiary settings. In a study of staff across three American universities, Benbow and Lees (2018) explored the development of social networks to support tertiary teaching. Using survey data from 224 academics and supplemented by 22 face-to-face interviews, analyses showed that network size, diversity and strength were correlated with years of teaching experience and organisational support.

One explicit way that tertiary institutions can support the development of social capital amongst staff is through peer observation of teaching programs. These programs have been implemented to support and inspire teachers in collaborative activity against a backdrop of diminishing resources (Georgiou, Sharma, \& Ling, 2018). Like student mentoring, peer observation of teaching for staff is associated with a range of benefits from individual and institutional perspectives, all of which can be related to social capital. From an individual perspective, benefits include reflective practice development (Bell, 2001; Lomas \& Nicholls, 2005), enhanced collegiality (Bell, 2001; Lomas \& Nicholls, 2005; Mager et al., 2014; White et 
al., 2014) and improved teacher efficacy (Hendry \& Oliver, 2012; Wright \& Main, 2015). From an institutional perspective, peer observation programs have evidenced a shift from teacherled to student-focused learning (Chester, 2012; Hounsell, 2009), enhanced student learning outcomes (Hanbury et al., 2008) and a focus on quality of teaching (Bell, 2001; Kell \& Annetts, 2009).

Peer observation of teaching is a contested term, but it is generally used to describe the practice of peers observing and providing feedback on each other's teaching practice. Within that broad conceptualisation of peer observation of teaching, multiple models exist, with distinct principles, practices, processes and purpose. These models include formative, diagnostic, summative and evaluative programs that are designed to focus on improving or evaluating teaching quality (Gosling, 2002; Lomas \& Kinchin, 2006; see Table 1). Programs typically focus on either continuous improvement processes, performance management, or providing evidence for academic promotion or advancement.

Table 1. Models used to describe peer observation of teaching.

\begin{tabular}{|c|c|c|}
\hline Model & Principles/Practices/Processes & Purpose \\
\hline Formative & $\begin{array}{l}\text { Observation, critical reflection, } \\
\text { appraisal, collegial exchange of } \\
\text { practices and improvement strategies. }\end{array}$ & $\begin{array}{l}\text { Continuous professional } \\
\text { development and improved } \\
\text { quality of teaching }\end{array}$ \\
\hline Diagnostic & $\begin{array}{l}\text { Review performed by experienced } \\
\text { academic }\end{array}$ & $\begin{array}{l}\text { Identifies and addresses } \\
\text { teaching practice issues }\end{array}$ \\
\hline Summative & $\begin{array}{l}\text { Review performed by experienced } \\
\text { academic or educational developer }\end{array}$ & Academic promotion \\
\hline Evaluative & $\begin{array}{l}\text { Peer observation performed by } \\
\text { experienced academic or management }\end{array}$ & $\begin{array}{l}\text { Authoritative diagnosis } \\
\text { of perceptions of } \\
\text { teaching }\end{array}$ \\
\hline
\end{tabular}

Note. Adapted from Gosling (2002) and Lomas and Kinchin (2006)

Formative peer observation of teaching programs, with an emphasis on collegial exchange, reflective practice, trust and relationship building, can be seen as an exchange that builds social capital. Models with a formative and collegial focus have generally been reported as more successful (Georgiou et al., 2018). The other forms of peer observation are designed to make judgements about performance for a range of purposes from probation to promotion. These models are typically characterised by unequal power relationships, where neither learning nor the relationship is the focus. As such these programs do not contribute positively to a social capital analysis.

While the concept of social capital has rarely been used to describe formative peer observation of teaching, both bonding and bridging social capital can be used to describe and explain the benefits that arise from formative approaches. In the rest of this section we examine these aspects. In contrast we could not find any examples of linking social capital in the peer observation of teaching literature. Partnering beyond the academy for observation of teaching does not seem to have yet been explored or is at least not yet well documented. Nevertheless it is possible to imagine contexts in which such partnerships could be used to build social capital. For example, teachers in primary, secondary and tertiary education could potentially provide useful feedback to each other and inform understandings of pedagogy and practice across these sectors. Partnerships between industry and educators focusing on teaching observation could also, with appropriate support, offer opportunities for strengthening connections and practice. 
A peer observation partner can play an important role in building social capital by assisting a peer in realising what "good" teaching represents (Gosling, 2009). Social capital can therefore be realised through engaging in peer observation as a practice foundational to academic scholarship. As with student mentoring, the functions of peer observation are diverse. These functions enable engagement with both informal and formal mechanisms within which social capital is enacted. Informal mechanisms may privilege building tacit forms of social capital.

Like student mentoring, peer observation of teaching is associated with a range of benefits. These benefits may be further conceptualised through the lens of structural, relational and cognitive dimensions of social capital (Nahapiet \& Ghoshal, 1998). The structural dimension of social capital refers to the factors that both influence relationship coherence within a social network and provide the relationship meaning and stability (Inkpen \& Tsang 2005). At a relational level different relationship types fuel different qualities of motivation, which in turn impacts the types of social capital gained. Informal structures may be more generative and sustaining of informal relationships, and are mediated by the quality of motivation governing the relational exchange. Where relationships exist within more visible structures, social sanctions may have a stronger bearing on the type and quality of relational exchange, including levels of reciprocity of knowledge exchange. Higher levels of reciprocity can contribute to increased trust, and enhanced motivation to exchange knowledge. Within peer observation, this may be evidenced in increased in teaching effectiveness (Hendry \& Oliver, 2012; Wright \& Main, 2015).

The quality of knowledge exchange may be contingent on the degree of a shared language, goal and culture. These commonalities form the cognitive dimension of social capital. Where language, goals and cultures are perceived to be shared, the relational dimension of social capital is more likely to be validated and exploited for mutual benefit. Realising these mutual benefits may reinforce the coherence of the social network and enhance access to important resources (Foley \& Edwards, 1999). Examples of these resources include exchange of emotional support (bonding) and access to information and resources (bridging) (Brass, Galaskiewicz, Greve \& Tsai, 2004). We explore these two aspects of bonding and bridging social capital more fully below.

Bonding social capital. In an example of peer observation that built bonding social capital within a discipline, Mager et al., (2014) describe a program for nursing academics at a small American university. Anticipated benefits of the program included cross course sharing, content suggestions, enhanced teaching and learning practices, improved student learning, staff satisfaction and success, work efficiency, and University effectiveness.

Twelve pairs of nursing faculty representing different levels of seniority and teaching experience observed each other's teaching and course materials. Participants negotiated their own focus and used a rubric to rate relevant aspects. The rubric included broad coverage such as organization, clarity, teaching strategies, presentation skills, use of technology content knowledge, humour and rapport, not all of which might be relevant to the particular partnership.

Although the concept of social capital is not discussed by Mager et al. (2014) results of a post-implementation focus group attended by seven staff revealed a number of strengths of 
the program that align with social capital principles. For example, a core outcome of the program was enhanced collaboration and collegiality. From a social capital perspective collaboration is a key factor in enabling people to examine assumptions and develop localised networks (Vallejos, Macke, Olea, \& Toss, 2008). Participants described the value of working with colleagues, using input from others in their own reflective practice and to improve their teaching. A particular feature of this model was the way it built on existing relationships. Core to this was the underlying role of trust. As one participant commented, "I loved the fact that we already knew each other, had a sense of each other's strengths and areas for growth most of us working together many years. A lot of the trust was already there." (p.5). Building on the trust that already exists is an important factor in developing social capital. Six, Zimmerman, Popa and Frison (2015) encourage organisations to create structures that "nourish" and "sustain" existing networks (p.151).

Bridging social capital. Many peer observation programs, like that described by Mager et al. (2014) pair staff within discipline areas. There are good reasons for doing this. Building social capital within teaching teams makes sense, can build on existing trust and evidence suggests staff imagine that only those who teach similar content will be able to understand and provide useful feedback on their practice (White, Boehm, \& Chester, 2014). However, the concept of bridging social capital suggests that value can also result from connections that extend beyond those already in one's network.

In our own work we have used peer observation to explicitly build social capital across disciplines. One example of this is a model we developed in a university health sciences school that included five distinct disciplines (Chester, 2012). Motivated by the stated desire to build social capital - to engage in reflective practice, improve student learning, and build closer connections between staff across the school - a small group came together to design a peer observation framework. The design phase included detailed conversations about the core features that would underpin the model resulting in consensus about the importance of the following: the program's voluntary and reciprocal nature (both members in a partnership would observe and be observed); individual autonomy to determine both the focus of the observation as well as the use of any data arising from the process; and a compulsory preobservation workshop to prepare participants, particularly for the processes of giving and receiving feedback.

The final area of agreement, with significance for the concept of bridging social capital, was a decision to pair participants across discipline areas. This decision was taken for two reasons. First, it was seen to encourage a focus on process and underlying pedagogy, rather than on the content of the class. Without disciplinary expertise partners could not focus on whether the teaching of the content was "right". Instead the group hypothesized that removing content-expertise would invite participants to focus on the learning and teaching experience, examine the processes being used and question the underlying pedagogy. Second, by pairing staff across disciplines outside existing power relationships the group hoped to reduce perceived vulnerability and threat. Cross-disciplinary partnerships were designed to build collegial networks beyond the discipline and help provide supportive relationships outside the politics of everyday work groups. Emphasis was on the development of a sustainable model of professional development that could accommodate staff at all levels of teaching experience, including permanent and sessional staff in a tertiary education setting.

The model was designed and trialled in Health Sciences, then rolled out in five other schools. Quantitative results from a survey of 15 staff who engaged in the pilot along with focus group 
data suggested the program enhanced collegial relationships between staff within schools as well as having a positive impact on pedagogy, self-efficacy and skill development. Table 2 provides a summary of post-implementation feedback.

Table 2. Self-reported outcomes of a staff peer observation of teaching program.

\begin{tabular}{lccc}
\hline $\begin{array}{l}\text { To what extent did participating in the } \\
\text { program help... }\end{array}$ & $\begin{array}{c}\text { Mean score } \\
\text { (out of 5) }\end{array}$ & SD & Score range \\
\hline Enhance relationships with your colleagues & 4.55 & 1.22 & $1-5$ \\
\hline Reflect on your teaching & 4.94 & 0.32 & $4-5$ \\
\hline Increasing your confidence in your teaching & 4.80 & 0.41 & $4-5$ \\
\hline Promote good teaching practice & 5.00 & 0.00 & - \\
\hline Develop new strategies or skills & 4.60 & 0.63 & 3.5 \\
\hline
\end{tabular}

Note. Adapted from Chester (2012)

Reflecting on the best aspects of engaging in the program, participants emphasized the opportunity to build collegiality across the school. As one participant commented, there was value in "meeting with other teachers and not feeling so isolated". The chance to share ideas and approaches and to do this within a reciprocal model was highly valued. As one participant noted, the best aspect of the program was to "share what is usually a very private space and get feedback on how this compares with others' classrooms". The program enhanced connections and provided access to resources outside the participants' day to day work.

An important finding of this study was a correlation between expressed vulnerability at the start of the program and perceptions the program had supported relationship development, suggesting that those who acknowledge vulnerability experience the greatest social capital gain. Instead of being a weakness of peer observations programs, vulnerability may be reconceptualized as a valuable and normal starting point.

A number of studies of peer observation of teaching have suggested the benefits of the programs extend beyond the capital accrued by and amongst the individual participants. As noted above advantages extend to students, who evidence improved academic performance (e.g., Hanbury et al., 2008; Lomas \& Nicholls, 2005; Venema, Drew, \& Lodge, 2015) as well as institutional gains that come with enhanced teaching quality (e.g., Bell, 2001; Kell \& Annetts, 2009).

\section{Conclusions}

Social capital is a concept that can be used to describe a number of relational practices that operate in tertiary institutions. In this chapter we have explored two of these: student peer mentoring and staff observation of teaching. Both approaches have been applied to improve learning and belonging and positively transform participant experience of tertiary education. Both are diverse in their implementation, with variations around key characteristics. Both have been implemented in cost-effective, sustainable and scalable ways. While social capital has rarely been applied to understand them, in this chapter we have explored ways in which the concept can help explain the benefits that arise for individuals and the value more broadly within the tertiary institutional context. Both practices use social capital to positively effect change - they connect participants into networks, leveraging the rich potential that already exists within tertiary settings. These practices build social capital, growing the number of ties, increasing participant confidence, strengthening and producing new norms and enhancing trust. 
The examples of social capital described in this chapter focused on separate student and staff networks in tertiary education. However, the benefits accrued in both spheres begs the question of the potential additional advantages that might arise from networks that deliberately engage students and staff together in collaborative work. Research in the emerging field known as students as partners explores how student and staff partnerships can enhance learning and engagement (Cook-Sather, Bovill, \& Felton, 2014; Healey, Flint \& Harrington, 2014). Initiatives in this area have been wide ranging, including curriculum design and pedagogy; learning, teaching and assessment; and scholarship of learning and teaching (Healey, Flint \& Harrington, 2014). A social capital analysis of these partnerships might add further weight to the significance of relationships to transform tertiary education.

Overtly valuing social capital can make for more productive and professionally satisfied teachers and more confident and engaged students. Growing social capital does not happen in a vacuum. If institutions want to positively transform themselves into thriving and productive environments of social cohesion, then a case for social capital may be just the lever for policy makers and senior management. Investing time and resources in appropriate partnerships amongst students and teachers offers critical opportunities for the future of education.

\section{References}

Adams, T., Banks, M., Davis, D., \& Dickson, J. (2010). The Hobsons retention project: context and factor analysis report. Melbourne, Australia: Hobsons Asia Pacific.

Baker-Doyle, K.J. (2013). The networked teacher: How new teachers build social networks for professional support. New York: Teachers College Press.

Barnard, A., Croft, A., Irons, R., Cuffe, N., Bandara, W., \& Rowntree, P. (2011). Peer partnership to enhance scholarship of teaching: a case study. Higher Education Research and Development, 30 (4), 435-448, DOI: 10.1080/07294360.2010.518953

Bell, M. (2001). Supported reflective practice: A program of peer observation and feedback for academic teaching development. International Journal for Academic Development, 6(1), 29-39.

Beltman, S., \& Schaeben, M. (2012). Institution-wide peer mentoring: Benefits for mentors. The International Journal of the First Year in Higher Education, 3 (2): 33-44.

Benbow, R., J., \& Lee, C. (2018). Teaching-focused social networks among college faculty: exploring conditions for the development of social capital. Higher Education, https://doi.org/10.1007/s10734-018-0331-5

Bourdieu, P. (1998). The forms of capital. In Richardson, J. (Ed). Handbook of theory and research for the sociology of education (pp.241-258). New York; Greenwood Press.

Bozeman, B., \& Feeney, M. (2007). Toward a useful theory of mentoring: A conceptual analysis and critique. Administration and Society, 39 (6), 719-739. 
Brass, D.J., J. Galaskiewicz, H.R. Greve, \& W. Tsai. (2004). Taking stock of networks and organizations: A multilevel perspective. Academy of Management Journal, 47, 795-817.

Burton, L.J., Chester, A., Xenos, S., \& Elgar, K. (2013). Peer mentoring to develop psychological literacy in first-year and graduating students. Psychology Learning and Teaching, 12 (2), 136-146. doi. 10.2304/plat.2013.12.2.136

Chester, A. (2012). Peer partnerships in teaching: Evaluation of a voluntary model of professional development in tertiary education. Journal of the Scholarship of Teaching and Learning, 12 (2), $94-108$.

Chester, A., Burton, L.J., Xenos, S., \& Elgar, K. (2013). Peer mentoring: Supporting successful transition for first year psychology students. Australian Journal of Psychology, 65, 30-37.

Coleman, J. (1988). Social capital in the creation of human capital. American Journal of Sociology, 94 Supplement, S95-S120.

Cook-Sather, A., Bovill, A., \& Felton, P. (2014). Engaging students as partners in learning and teaching: A guide for faculty. San Francisco: Jossey Bass.

Crisp, G., \& Cruz, I. (2009). Mentoring college students: A critical review of the literature between 1990 and 2007. Research in Higher Education, 50, 525-545. doi:10.1007/s11162-009-9130-2

Dewey, J. (1900). The elementary school record. Chicago: Chicago University Press.

Douglass, A.G., Smith, D.L., \& Smith, L.J. (2013). An exploration of the characteristics of effective undergraduate peer-mentoring relationships, Mentoring \& Tutoring: Partnerships in Learning, 21 (2), 219-234 doi: 10.1080/13611267.2013.813

Egege, S., \& Kutieleh, S. (2015). Peer mentors as a transition strategy at University: Why mentoring needs to have boundaries. Australian Journal of Education, 59 (3), 265-277, https://doi.org/10.1177/0004944115604697

Ehrich, L.C., Hansford, B., \& Tennent, L. (2004). Formal mentoring programs in Education and other professions: A review of the literature. Educational Administration Quarterly, 40 (4), 518-540

Farr, J. (2004). Social Capital: A conceptual history. Political Theory, 32 (1), 6-33.

Field, J. (2008). Social capital. Abingdon, Oxon: Routledge.

Foley, M.W., \& Edwards, B. (1999). Is it time to disinvest in social capital? Journal of Public Policy, 19, 141-73.

Fox, A., Stevenson, L., Connelly, P., Duff, A., \& Dunlop, A. (2010). Peer-mentoring undergraduate accounting students: The influence on approaches to learning and 
academic performance. Active Learning in Higher Education, 11 (2), 145-156.

https://doi.org/10.1177/1469787410365650

Fukuyama, F. (1995). Social capital and the global economy. Foreign Affairs, 74 (5), 89-103.

Georgiou, H., Sharma, M., \& Ling, A. (2018) Peer review of teaching: What features matter? A case study within STEM faculties. Innovations in Education and Teaching International, 55 (2), 190-200, doi: 10.1080/14703297.2017.1342557

Gannon, J. M., \& Maher, A. (2012). Developing tomorrow's talent: The case of an undergraduate mentoring programme. Education + Training, 54, 440-455. doi:10.1108/00400911211254244

Gerschenfeld, A. (2014). A review of undergraduate mentoring programs. Review of Educational Research, 84, 365-391.

Goff, L. (2011). Evaluating the outcomes of a peer-mentoring program for students transitioning to postsecondary education. Canadian Journal for the Scholarship of Teaching and Learning, 2(2), 1-12. doi:10.5206/cjostl_rcacea.2011.2.2

Haggard, D., Dougherty, T., Turban, D., \& Wilbanks, J. (2011). Who is a mentor? A review of evolving definitions and implications for research. Journal of Management, 37, 280-304. doi:10.1177/0149206310386227

Hall, R., Jaugietis, Z. (2011). Developing peer mentoring through evaluation. Innovative Higher Education, 36 (1), 41-52.

Halpern, D. (2005). Social capital. Cambridge: Polity Press.

Hanbury, A., Prosser, M., \& Rickinson, M. (2008). The differential impact of UK accredited teaching development programmes on academics' approaches to teaching. Studies in Higher Education, 33(4), 469-483.

Hanifan, L. J. (1912). The rural school and rural life. West Virginia School Journal, 4, 204-207.

Healey, M., Flint, A., \& Harrington, K. (2014). Engagement through partnership: students as partners in learning and teaching in higher education. UK: The Higher Education Academy.

Hendry, G. D., \& Oliver, G. R. (2012). Seeing is believing: The benefits of peer observation. Journal of University Teaching \& Learning Practice, 9 (1), 7.

Hezlett, S.A., \& Gibson, S.K. (2007). Linking mentoring and social capital: implications for career and organization development. Advances in Developing Human Resources, 9 (3), 384-412.

Hounsell, D. (2009). Evaluating courses and teaching. A handbook for teaching and learning in higher education: Enhancing academic practice, 198-211. 
Hryciw, D. H., Tangalakis, K., Supple, B., \& Best, G. (2013). Evaluation of a peer mentoring program for a mature cohort of first-year undergraduate paramedic students. Advances in Physiology Education, 37, 80-84. http://dx.doi.org/10.1152/advan.00129.2012

Inkpen, A.C., and E.W.K. Tsang. 2005. Social capital, networks and knowledge transfer. Academy of Management Review, 30, 146-65.

Jacobi, M. (1991). Mentoring and undergraduate academic success: A literature review. Review of Educational Research, 61, 505-532. doi:10.3102/00346543061004505

Jones, M.M., \& Goble, Z. (2012). Creating effective mentoring partnerships for students with intellectual disabilities on campus. Journal of Policy and Practice in Intellectual Disabilities, 9, 270- 278. https://doi.org/10.1111/jppi.12010

Kehoe, D. (2007). Developing your people: 25 action-based articles showing you how to develop your people through coaching and mentoring. Australia: McGraw Hill.

Kell, C., \& Annetts, S. (2009). Peer review of teaching embedded practice or policy-holding complacency? Innovations in Education and Teaching International, 46, 61-70.

Lin, N. (2001). Social capital: A theory of social structure and action. Cambridge University Press: Cambridge.

Lomas, L., \& Kinchin, I. (2006). Developing a peer observation program with university teachers. International Journal of Teaching and Learning in Higher Education, 18(3), 204214.

Lomas, L., \& Nicholls, G. (2005). Enhancing teaching quality through peer review of teaching. Quality in higher education, 11(2), 137-149.

Mager, D. R., Kazer, M. W., Conelius, J., Shea, J., Lippman, D. T., Torosyan, R., \& Nantz, K. (2014). Development, implementation and evaluation of a peer review of teaching (PRoT) initiative in nursing education. International journal of nursing education scholarship, 11(1), 113-120.

Mekolichick, J., \& Gibbs, M. (2012). Understanding college generational status in the undergraduate research mentored relationship. Council on Undergraduate Research Quarterly, 33(2), 40-46.

Nahapiet, J., \& S. Ghoshal. 1998. Social capital, intellectual capital and the organizational advantage. Academy of Management Review 23: 242-66.

Parr, N. (2015). Who goes to university? The changing profile of our students. The Conversation. May 25, 2015. https://theconversation.com/who-goes-to-university-thechanging-profile-of-our-students-40373

Paxton, P. (1999). Is social capital declining in the United States? A multiple indicator assessment. American Journal of Sociology, 105, 88-127. 
Putnam, R.D. (2000). Bowling alone: The collapse and revival of American community. New York: Simon \& Schuster.

Putnam, R.D., Leonardi R., \& Nanetti, R. (1993). Making Democracy Work: Civic Traditions in Modern Italy. Princeton: Princeton University Press.

Skaniakos, T., Penttinen, L., \& Lairio, M. (2014). Peer group mentoring programmes in Finnish higher education: Mentors' perspectives. Mentoring \& Tutoring: Partnership in Learning, 22 (1), 74-86 doi: 10.1080/13611267.2014.882609

Six, B., van Zimmeren, E., Popa, F. \& Frison, C., 2015. Trust and social capital in the design and evolution of institutions for collective action. International Journal of the Commons, 9(1), pp.151-176. DOI: http://doi.org/10.18352/ijc.435

Stone, W. \& Hughes. J. (2000). What role for social capital in family policy? Family Matters, $56,20-27$.

Terrion J. L., \& Leonard D. (2007). A taxonomy of the characteristics of student peer mentors in higher education: Findings from a literature review. Mentoring \& Tutoring: Partnership in Learning, 15 (2), 149-164.

Vallejos R.V., Macke J., Olea P.M., \& Toss E. (2008). Collaborative Networks and Social Capital: A Theoretical and Practical Convergence. In: Camarinha-Matos L.M., Picard W. (eds) Pervasive Collaborative Networks. PRO-VE 2008. IFIP - The International Federation for Information Processing, 283. Springer, Boston, MA doi: 10.1007/9780-387-84837-2_5

Venema, S., Drew, S., \& Lodge, J.M. (2015). Peer Observation as a Collaborative Vehicle for Innovation in Incorporating Educational Technology into Teaching : a case study. In C. Klopper \& S. Drew (Eds.), Teaching for Learning and Learning for Teaching (pp. 209-225). Rotterdam: Sense Publishers.

White, K., Boehm, E., \& Chester, A. (2014). Predicting academics' willingness to participate in peer review of teaching: A quantitative investigation. Higher Education Research and Development, 33 (2), 372-385. doi: 10.1080/07294360.2013.832162.

Woolcock, M. (2001). The place of social capital in understanding social and economic outcomes. Isuma: Canadian Journal of Policy Research, 2, 1-17.

Wright, O., \& Main, K. (2015). Analysing Peer Pedagogic Practices as a Positive Contribution to Academic Professional Development. In C. Klopper \& S. Drew (Eds.), Teaching for Learning and Learning for Teaching (pp. 117-133). Rotterdam: Sense Publishers. 


\section{University Library}

\section{- M M N E R VA A gateway to Melbourne's research publications}

Minerva Access is the Institutional Repository of The University of Melbourne

\section{Author/s:}

Johnston, A;Chester, A;Clarke, A

Title:

Partnerships for Learning and Belonging in Tertiary Education: A Social Capital Analysis

Date:

2019

Citation:

Johnston, A., Chester, A. \& Clarke, A. (2019). Partnerships for Learning and Belonging in Tertiary Education: A Social Capital Analysis. Tynan, B (Ed.). McLaughlin, T (Ed.). Chester, A (Ed.). Hall-van den Elsen, C (Ed.). Kennedy, B (Ed.). Transformations in Tertiary Education, (1), pp.11-26. Springer Nature Singapore.

Persistent Link:

http://hdl.handle.net/11343/274378 